SINIŠA VILKE, Ph.D. ${ }^{1}$

E-mail: svilke@pfri.hr

DAVOR MANCE, Ph.D. ${ }^{2}$

E-mail: davor.mance@efri.hr

BORNA DEBELIĆ, Ph.D. ${ }^{1}$

E-mail: debelic@pfri.hr

MARINKO MASLARIĆ, Ph.D. ${ }^{3}$

(Corresponding author)

E-mail: marinko@uns.ac.rs

${ }^{1}$ University of Rijeka, Faculty of Maritime Studies

Studentska ulica 2, 51000 Rijeka, Croatia

${ }^{2}$ University of Rijeka, Faculty of Economics

Ul. Ivana Filipovića 4, 51000 Rijeka, Croatia

${ }^{3}$ University of Novi Sad, Faculty of Technical Sciences

Trg Dositeja Obradovića 6, 21000 Novi Sad, Serbia
Transport Economics

Original Scientific Paper

Submitted: 2 Sep. 2020

Accepted: 26 Mar. 2021

DOI: $10.7307 /$ ptt.v33i4.3688

\title{
CORRELATION BETWEEN FREIGHT TRANSPORT INDUSTRY AND ECONOMIC GROWTH - PANEL ANALYSIS OF CEE COUNTRIES
}

\begin{abstract}
The paper tests for statistical association between employment and value added of freight transport industry and its component activities against overall economy in a ten-year panel ranging from 2008 to 2017 of the thirteen newest European Union member countries. In this paper, the nature of correlation between economic growth as the independent variable and freight transport industry as a dependent variable is examined. To achieve stationarity, and to lose autocorrelation and the idiosyncratic effects, the variables are first differenced. The results of the "Granger causality" tests show the null hypothesis of no-causation may be rejected for most conjectures with high F-Statistics as well as high statistical significance. The results of the Panel EGLS cross-section fixed effects do not reject the results gained by the Granger test, and the same may be said for the Panel Generalised Method of Moments First Differences test. The result of the Arellano-Bond test shows no serial correlation in the residuals. It has been concluded that changes in overall economy (value added and employment) have a significant and measurably strong impact on freight transportation and warehousing sector. This conclusion is useful in assessing future impacts on freight transport industry, especially as a consequence of contingent events.
\end{abstract}

\section{KEYWORDS}

freight transport industry; logistics; economic growth; panel analysis; relationship.

\section{INTRODUCTION}

The fact that changes in overall economic activity cause changes in its component industries is an intuitively attractive hypothesis worth testing. For example, any significant disruption in the overall economy should intuitively cause a disruption in the overall logistics (as integration of transportation, warehousing, handling, freight forwarding, and information services). However, this relationship is mutual and autoregressive, meaning that economic growth stimulates transport and logistics demand, but on the other hand, transport development represents the main requirement and support to the overall economic development. That is, efficient, smooth, and low-cost logistics makes significant contributions to the economy and general prosperity of a country [1]. Therefore, transport and business systems are strongly correlated $[2,3]$ and defining the nature of the relationship between business, economic development, and transport activities are topics worth analysing at both national and international level, as already stated in [4]. The characteristics of this relationship are analysed in a number of papers, but most of them are focused on the linkage between the development of logistics and manufacturing, financial, or some other particular type of industries, with just a few papers related 
to the relationship between the freight transport and logistics industry and the national or global economy [5]. A similar conclusion is made in [6], where it is stated that the problem of assessment of transportation and logistics developments and an impact of investment on economic development and vice versa, is not new in literature, and the number of papers devoted to measuring the impact of logistics development on regional or global economic development is far less numerous.

Since the outbreak of the international financial crisis, the importance of knowing the exact correlation between transportation industry and economic development has changed notably. After the 2008 crisis, the debate within research literature focused on the length and severity of the impacts on freight transport, with the final aim of projecting future trajectories of economic and freight transport development. For example, [7] had estimated that economic crises caused a time delay of five years for the expected freight transport development. Based on this estimation, the paper [8] had concluded that: "domestic freight transport levels at central European countries remained almost stable during the first three years since 2008, while international freight transport has been hit almost proportionally to the losses in global trade (10\% on the average)". All European countries faced similar situations with the decrease in their annual transport performance. According to official statistical data, the impact of the global economic crisis on the transport sector has varied from country to country. In some countries, the economic crisis hit the transport sector even more than the overall economic activity. Therefore, it is very important to accurately determine the relationship and correlation between levels of economic and freight transport activities for a particular country or group of countries (region) that have similar characteristics and position in the global economy. Knowing of this relationship could be very useful in assessing the impact of some future global economy disturbance, such as the COVID-19 outbreak, on freight transport and logistics.

In this paper, a ten-year panel from 2008 to 2017 of thirteen newest European Union member countries was analysed, mainly from the region of the Central and Eastern Europe (CEE): Bulgaria, Czech Republic, Croatia, Estonia, Hungary, Lithuania, Latvia, Poland, Romania, Slovenia, and Slovakia together with the Mediterranean island countries of Cyprus and Malta, in order to examine the relation- ship between value added of the overall economy against the value added of the freight transportation industry and its activities.

First, the data was differenced to achieve stationarity and to lose the idiosyncratic effects (effects particular of individual countries) present in the coefficients, and the variables representing the overall economy (value added, employment, number of enterprises) were regressed on variables representing the freight transportation industry. The main challenge was to test the conjecture whether or not, and if so, by how much the changes in the overall economy (its value added) had a statistically significant and measurably strong impact on freight transportation and warehousing section divisions. Although there have been some sectoral analyses in the past [9], as far as we know, there have been no studies analysing these relationships on the dataset comprising the thirteen CEE countries between 2008 and 2017 or any other recent time period. The main expectations were to elicit some new knowledge about the given topic and provide scientifically grounded facts useful for future recommendations, plans, and strategies of freight transport industry development. Our null hypothesis was the one of no correlation between the economic growth as the independent variable and transport industry as a dependent variable. We aimed at rejecting it with statistical significance levels of well below $\mathrm{p}<0.05$.

\section{LITERATURE REVIEW}

Freight transport is a significant factor of timely and spatial economic utility for production and services within the logistics chain going from the supplier to the final customer [10]. Transport is a core component of logistics, important in terms of the speed and reliability of moving goods [1]. With the gradual transport and logistics boom it has been transformed in its role, requirements, general concept, and importance [11]. One of the most common indicators for measuring country's freight transport and logistics efficiency is logistics costs-to-GDP ratio. Calculation of such a ratio requires adequate knowledge of logistics costs (classification of logistics activities, methodology of calculation, and data). The logistics costs-to-GDP ratio for developing countries is twice that of well-developed countries. For example, for the US, Germany, Japan this amounts to around $8 \%$, whereas for countries such as China, Mexico, and India this goes to almost $20 \%$ [1]. According to the same authors, transport 
costs are a dominant cost category within the costs of logistics, and represent more than $50-60 \%$ of total logistics costs. Hence, freight transport is a very important logistics activity, and their importance will rise in the future as the pace of transformation in economic development advances and the industrial strategy shifts to high-technology and knowledge-based industries, as well as digitised and automated processes [12].

In regard to the analysis of the impact of economic development on transport, a couple of different approaches and methodologies were used in the past ranging from a simple analysis of available data to sophisticated statistical correlation techniques [8]. A very good literature review on this topic could be found in $[4,8,13,14]$. In [4] authors claimed that in most of the analysed cases, the GDP is used to present the economic growth even when other indicators could be used instead. Most of the papers which are analysed in [4] corroborate the idea of a strong relationship between transport and economic growth. In [8] authors stated that correlation between economic and transport development as a research topic was prompted after the promotion of EU's policy for "decoupling", which tried to disconnect the growth in freight transport rates from the growth of the economy. They analysed several papers regarding relations between freight transport and economic indicators. In these papers the following principal indicators of economic activity appear: the GDP, industrial production, imports and exports volume, and employment per sector. Moreover, the following freight transport indicators appear: the ton- $\mathrm{km}$, number of vehicle trips, number of $\mathrm{km}$ driven. These studies are mainly based on time series data analyses which are used to construct some mathematical relations through statistical correlation and regression analyses. In [13] the authors reviewed several papers where the GDP is again the main indicator of economic growth, whereas for the freight transport and logistics industry we have indicators such as: logistics industry added value, total employment in the logistics industry, freight volume, and traffic turnover volume. Based on the time series data analysis and the logistic model, [13] confirmed a strong relationship between logistics development and economic growth. According to $[13,14]$, the problems regarding the correlation between freight transport and economic growth were tackled by many authors. In their own research in [14], the authors examined and quantified the main driving factors that determine the changes in freight ton-km as an indicator of freight transport development. They concluded that economic growth was the main driver for increasing the freight ton- $\mathrm{km}$.

The paper [15] also concludes that GDP is widely accepted as the most comprehensive measure of economy size, and that transport as the economy's component is often measured against GDP. However, this paper stated the problem that the relationship between transport and economy is multi-faceted, and measures of transport in relation to GDP are not always based on a conceptual framework that explicitly and accurately reflects the underlying relationships. Hence, they proposed a new conceptual framework which focuses on defining transport and measures of transport thus defined in more detail. The existence of a positive correlation between the development of freight transport and GDP in China is shown in paper [16]. However, the same author found that the correlation degree between transportation structure changes in transport and Chinese national economy is different (civil aviation, railway freight, and GDP has greater correlation), as is different the level of correlation during the different historical stages (the period between 1978 and 1995 presents less correlation than the period from 1995 to now). The final aim of exploring this relationship was getting a signal for early detection of extremely "hot" or "cold" development problems in transport, which could help with a better understanding of macroeconomic trends in the country, as well as providing the basis for risk warning of freight transportation industry. That the correlation between freight transport and GDP exists is also shown in paper [17]. Nevertheless, this paper claimed that the real cause-effect relationship between these two variables is not yet fully known. Based on the analysis of two countries' data, it was shown that for the same global GDP growth, very different road freight transport volumes could be expected depending on the type of economic activity in a certain country, which means that freight transport could have fluctuated depending on the evolution of the structure of the economy. Similar to the most of other studies, the paper [18] also analyses relationships between transport and economy on the country level. The investigation of the link between freight transport and the economic growth for a European panel of countries (only five countries: Belgium, Denmark, Germany, France, and the Netherlands) has been done in [18]. This paper results have shown that freight 
transport intensity with respect to the economic production is not constant. As a conclusion, the author of this paper has stated that such an investigation should be applied in more countries in order to get a clearer picture about the evolution in relationships of these factors.

The paper [19] examined effects of logistics performance in international trade using cross-country data for a large sample of countries. According to this paper, the existing studies have emphasised the effects of logistics on the economic growth or trade, while very few papers address the specificities or the dimensions that determine the economic activity and their effects on the efficiency of logistics activity. In any case, this paper certainly showed strong evidence of the positive role that the logistics plays in an increasing global economy and trade. The question of how much freight transportation is generated by which economic activities is analysed in [20]. Using historical data for Germany, this paper developed an economic indicator with which the interdependency between 59 types of industries and the amount of 24 types of transported goods is demonstrated. As the final result, this paper found a strong interdependency between the majority of the transported goods and the developed economic indicator. However, the whole analysis is done for only one country.

Based on the literature review, it can be said that economic activities imply freight transportation and vice versa, but exploring this relationship between freight transport and economy efficiency rely mostly on national level performance (considering country as the unit of analysis). Hence, the initiative to explore this relationship for a whole region of central and east Europe certainly represents a contribution to the existing literature, within the meaning of possible comparison of results between the "new" and "old" EU member states. Keeping all of the above in mind, we developed the following hypothesis: "Freight transport and business systems in thirteen newest EU member states are correlated, within the meaning that changes in their overall economy performance (value added and employment) have a statistically significant impact on freight transportation and warehousing sector variables".

\section{DATA AND METHODS}

Apart from the already mentioned content-related purpose of this paper, which is to statistically test and investigate the nature of relationship between the economic and freight transport development, the aspiration from the methodological point of view is to demonstrate the usefulness and purposefulness of using secondary data in empirical transport and logistics research. Using secondary type of data seems appropriate in cases with a high possibility that primary collected data will duplicate that which are already available, as well as in cases with the existence of comprehensive and regular statistical reports, such as in the case of the transport sector. In addition, the usage of secondary data sources has been encouraged by [21], who stated both the main benefits of using secondary data and the types of tools and techniques that can be used for their analysis, by [22], who claimed that secondary data could be effective in supply chain research in addressing a number of topic areas such as sustainability, financial performance and more, as well as by [23] who established one of the first methodologies for the use of secondary data in logistics research.

As already mentioned, this paper analysed a tenyear panel from 2008 to 2017 of thirteen newest EU member states: Bulgaria, Cyprus, Czech Republic, Estonia, Croatia, Hungary, Lithuania, Latvia, Malta, Poland, Romania, Slovenia, and Slovakia. Because the number of employees and the number of enterprises is not an adequate measure of the development of freight transport industry, we use the total value added for the industry, as well as for its constituent sectors. We used sectorial data for the non-financial business economy according to the NACE nomenclature from B-J and L-N [24]. We specifically put under scrutiny the data representing $\mathrm{H}$ : Transportation and storage industrial section according to the accepted NACE industry classification [25]. The NACE classification recognises Sections (A-U), Divisions (01-99), Groups (01.1-99.0), and Classes (01.11-99.0). The industry under our scrutiny is found in the NACE nomenclature between $\mathrm{H}: 49.11$ and $\mathrm{H}: 53.20$. We analysed a ten-year panel of the above mentioned thirteen CEE countries and the influence of the value added (VA) of their total economies on the value added (VA) of their specific $\mathrm{H}$ : Transportation sectors. We first-differenced the data to achieve stationarity, and regressed the total value added of the overall economy onto the value added, number of employees, and the number of enterprises of its component activities of the H: Transportation and storage industry. The component activities (divisions in NACE classification) are:

- H49: Land transport and transport via pipelines 
- H50: Water transport

- H51: Air transport

- H52: Warehousing and support activities for transportation

- H53: Postal and courier activities.

Firstly, the data for unit root processes were tested using several tests simultaneously. After achieving stationarity by differencing the data, a Panel Pairwise Granger Causality test between the first differences of all relevant variables was performed. Only when weak data stationarity was achieved, were we able to proceed. Strong stationarity in form of Gaussian normality is not an important condition for the Granger causality test but an absence of statistically significant trends is. By differencing the data we removed the trends, the fixed effects and autocorrelation. The Panel Pairwise Granger Causality test is a useful tool to determine potential statistical relationships. These are further tested with more stringent tests. The first of these is the Panel Estimated Generalised Least Squares (EGLS) test between first-differences of the overall economy value added, as well as transportation and storage sector variables value added, regressed on the value added, number of employees, and number of enterprises in of the $\mathrm{H}$ : transportation and storage sector activities (from $\mathrm{H} 49$ to H53) in 13 CEE countries.
Lastly, we performed a Panel Generalised Method of Moments (GMM) First Differences (FD) test on the same variables. With GMM FD we checked for unobserved heterogeneity among countries when this heterogeneity is constant over time. Since lags of the dependent variable are necessarily correlated with the idiosyncratic error, we tested the residuals using the Arellano-Bond GMM estimator [26]. All calculations were performed using the Eviews 9 statistical analysis software by IHS Global Inc.

\section{RESULTS AND DISCUSSION}

Before testing the data for Granger causality, correlation, and moment, the data for unit roots were tested. The test statistics summary is shown in Table 1, which shows that the null hypothesis of a unit root process cannot be rejected. We thus differenced the data to achieve full stationarity and regressed various variables of the overall economy (value added, employment, number of enterprises) on Warehousing.

Summary results in Table 2 show that the null hypothesis of the existence of a unit root process may be rejected at the $\mathrm{p}<0.05$ level. The results of the Panel Pairwise Granger Causality tests are shown in Table 3.

Table 1 - Example of table caption

\begin{tabular}{||l|c|c|c|c||}
\hline \multicolumn{1}{||}{ Method } & Statistic & Prob. & Cross-sections & Obs \\
\hline \hline \multicolumn{2}{|c|}{ Null: Unit root (assumes common unit root process) } \\
\hline Levin, Lin \& Chu t* & -0.99679 & 0.1594 & 13 & 104 \\
\hline Breitung t-stat & 3.50677 & 0.9998 & 13 & 91 \\
\hline \multicolumn{7}{|c|}{ Null: Unit root (assumes individual unit root process) } \\
\hline Im, Pesaran and Shin W-stat & 1.05535 & 0.8544 & 13 & 104 \\
\hline ADF - Fisher Chi-square & 20.4967 & 0.7675 & 13 & 104 \\
\hline PP - Fisher Chi-square & 94.2244 & 0.0000 & 13 & 117 \\
\hline
\end{tabular}

Data source: [24]; Calculation: Eviews 9.0.

Table 2 - Panel unit root test summary of the CEE countries value added after differencing

\begin{tabular}{||l|c|c|c|c||}
\hline \multicolumn{1}{||}{ Method } & Statistic & Prob. & Cross-sections & Obs \\
\hline \hline \multicolumn{7}{|c|}{ Null: Unit root (assumes common unit root process) } \\
\hline Levin, Lin \& Chu t* & -10.5565 & 0.0000 & 13 & 91 \\
\hline Breitung t-stat & -4.54112 & 0.0000 & 13 & 78 \\
\hline \multicolumn{7}{|c|}{ Null: Unit root (assumes individual unit root process) } \\
\hline Im, Pesaran and Shin W-stat & -1.66270 & 0.0482 & 13 & 91 \\
\hline ADF - Fisher Chi-square & 57.7220 & 0.0003 & 13 & 91 \\
\hline PP - Fisher Chi-square & 156.050 & 0.0000 & 13 & 104 \\
\hline
\end{tabular}

Data source: [24]; Calculation: Eviews 9.0. 
The above is an example of the overall approach used in the paper. Thus, after testing for stationarity and after achieving stationarity with first differencing the variables, we proceed with Panel Pairwise Granger Causality tests. The test results are shown in Table 3 on a pairwise basis. The letter D before the parentheses means first difference of the variable in the parentheses.

The results in rows 1 and 2 (Table 3) show the fulfilment of at least the weak form of independence between two major variables in our analysis: the change in the value added of the overall economy and the change in the value added of the transportation sector. Thus, by being independent, all other variables may be put into a Granger causality conjecture without fear of autocorrelation. To prevent any potential adverse effects of non-stationarity, all variables are first-differenced. Thus, we speak of Granger causality between changes and not between their absolute values.

The relationship found in row 3 (Table 3) between the change in the total value added and the change in the value added of the $\mathrm{H}: 49$ Land transport division of the H: Transport and storage section cannot be rejected (F-statistic $>8.05, \mathrm{p}<0.01$ ). Granger causality between the change in the total value added and the change in the value added of the H:50 Water transport may be rejected at the $\mathrm{p}<0.1$ significance level. We conclude that Water transport is not significantly influenced by the overall economic activities bearing in mind that the variables have a time lag of 1, meaning 1 year. The Granger causality between total economic value added and H51: Air transport found in row 5 of Table 3 may not be rejected, although the correlation is quite weak (F-statistic $=4.97, \mathrm{p}<0.028$ ). Row 6 of Table 3 shows one of the strongest Granger causations between the total value added of the overall economic activity and the H:52 Warehousing division of the H: Transportation and storage section (F-statistic $=29.64$, $p=4 \cdot 10-7)$. Lastly, the Postal and courier activities division (H:53) does not seem to be under any Granger causation from the overall economic activity represented by the value added from all sections (B-J and L-N). Instead, the inverse relationship seems to hold ground, which is what we need to test in continuation. Postal and courier activities are an integral and statistically significant part of the total value added of the analysed economies, as shown in row 8 of Table 3. In other words, any change in the overall economic activity of the measured panel of the 13 CEE countries is preceded by a change in the H53: Postal and courier service activities' value added. Row 9 of Table 3 shows the highest result in terms of F-statistic (30.76) and in terms of statistical significance $(p=2 \cdot 10-7)$. This means that we may reject the null-hypothesis of no Granger causation going from the change in the total value added of the

Table 3 - Results of the Panel Pairwise Granger Causality test (104 observations, lag 1)

\begin{tabular}{|c|l|c|c||}
\hline Nr. & \multicolumn{1}{|c|}{ Null hypothesis: } & F-Statistic & Prob. \\
\hline \hline 1 & D(VA ALL TOTAL) does not Granger Cause D(VA HTOTAL) & 0.08925 & 0.7657 \\
\hline 2 & D(VA H TOTAL) does not Granger Cause D(VA_ALLTOTAL) & 0.25402 & 0.6154 \\
\hline 3 & D(VAALLTOTAL) does not Granger Cause D(VA H49TOTAL) & 8.04956 & 0.0055 \\
\hline 4 & D(VA ALL TOTAL) does not Granger Cause D(VAH50TOTAL) & 3.32533 & 0.0712 \\
\hline 6 & D(VAALLTOTAL) does not Granger Cause D(VA H51TOTAL) & 4.96534 & 0.0281 \\
\hline 7 & D(VAALLTOTAL) does not Granger Cause D(VAH52TOTAL) & 29.6401 & $4 \cdot 10^{-7}$ \\
\hline 8 & D(VAH53TOTAL) does not Granger Cause D(VA ALLTOTAL) & 0.35416 & 0.5531 \\
\hline 9 & D(VAHTOTAL) does not Granger Cause D(VA H52 TOTAL) & 22.0541 & $8 \cdot 10^{-6}$ \\
\hline 10 & D(VAH51TOTAL) does not Granger Cause D(VA H49TOTAL) & 30.7623 & $2 \cdot 10^{-7}$ \\
\hline 11 & D(VA H49TOTAL) does not Granger Cause D(VA H51TOTAL) & 8.95265 & 0.0035 \\
\hline 12 & D(VAH49TOTAL) does not Granger Cause D(VAH52TOTAL) & 7.10046 & 0.0090 \\
\hline 13 & D(VA H53TOTAL) does not Granger Cause D(VA H49TOTAL) & 26.8401 & $1 \cdot 10^{-6}$ \\
\hline 14 & D(VAH53TOTAL) does not Granger Cause D(VAH52TOTAL) & 9.21012 & 0.0031 \\
\hline 15 & D(VA H52TOTAL) does not Granger Cause D(VA H53TOTAL) & 19.8065 & $2 \cdot 10^{-5}$ \\
\hline 16 & D(VA H TOTAL) does not Granger Cause D(VA H51TOTAL) & 13.2818 & 0.0004 \\
\hline \hline
\end{tabular}

Data source: [24]; Calculation: Eviews 9.0. 
$\mathrm{H}$ : Transportation and storage section and its $\mathrm{H}: 52$ Warehousing division. Row 12 of Table 3 shows the results of the Granger causality test between H49: Land transport and H52: Warehousing. High F-statistic of 26.8401 with $\mathrm{p}=1 \cdot 10-6$ means we cannot reject the hypothesis of Granger causation going from land transportation to warehousing. Row14 of Table 3 shows Granger causality between changes in the value added of H53: Postal and courier services and changes in the value added of H52: Warehousing and support activities of the transportation section. The F-statistic of 19.8065 shows a strong relationship, and the p-value of $2 \cdot 10-5$ indicates that we may reject the null hypothesis of no causation.

The rest of Table 3 shows other Granger causality test results with somewhat weaker F-statistics and p-values. Panel data models can have heteroscedasticity and autocorrelation between errors both contemporaneously and over time. In such cases it is advised to use the Panel EGLS method. The Panel EGLS method is a generalization of the Ordinary Least Squares (OLS) method, with the difference of relaxing the assumption of errors being homoscedastic and uncorrelated. By default, Eviews gives all observations an equal weight in estimation. We used cross-section weights to estimate a feasible GLS specification in the presence of cross-section heteroscedasticity that is due to differences between the 13 CEE countries. The results are shown in Table 4.

Firstly, we showed the impact that the changes in total value added of the overall economy have on various divisions of the $\mathrm{H}$ : section. For purposes of data stationarity, as before, all variables are differenced. After differencing, the results are once more tested for stationarity. Due to differencing, we speak of changes in variables and not in their nominal values. The sample of the 13 CEE countries, loses 1 year of data due to differencing and thus has $9 \cdot 13=117$ observations.

The equation results are statistically significant at $p<0.01$ level except for H53 where they are not statistically significant at the 0.05 level and may thus be rejected. On the basis of the entire Panel EGLS test results, we may conclude that the conjecture of the positive relationship between the total value added of the $13 \mathrm{CEE}$ as the independent variable and the overall and particular $\mathrm{H}$ : activities of the transportation sector between 2008 and 2017, cannot be rejected except for the H53: Postal and courier services being not influenced by the overall value added. All other divisions of the $\mathrm{H}$ : Transportation and storage section are clearly caused by the economic activity represented by the value added of the 13 CEEs.

We proceed now with a Panel Generalised Method of Moments First Differences model, as a much more stringent statistical test not prone to autocorrelation and other problems found in Panel EGLS. An example of the test procedure is given in Table 5, and other tests are summarised in Table 7. The summary of Table 5 can be found in row 4 of Table 7 .

The vector of the H49: Land transport value added is under statistically significant $(\mathrm{p}<0.001)$ influence of the overall economies' value added, though this influence is not strong in absolute terms (Coefficient value $=0.055$ ). Most of the effect is carried by the inertial autoregression (Coefficient value $=0.129$ ). The J-statistic states that the instruments are uncorrelated with the error term and the Prob(J-statistic) significantly different from zero (0.39) gives us the confidence that our instrument

Table 4 - Results of the Panel EGLS cross-section fixed effects with weights

\begin{tabular}{||c|c|c|c|c|c|c|c|c|c||}
\hline \hline Nr. & Dependent & Independent & Coefficient & Std. Error & Prob. & Constant & Std. Err. & Prob. & R2 \\
\hline \hline 1 & D(VA H49) & D(VA ALL) & 0.048228 & 0.002660 & 0.0000 & 15.70784 & 3.412587 & 0.0000 & 0.78 \\
\hline 2 & D(VA H50) & D(VA ALL) & 0.000369 & 0.000112 & 0.0014 & -4.5897 & 0.439065 & 0.0000 & 0.20 \\
\hline 3 & D(VA H51) & D(VA ALL) & 0.003009 & 0.000494 & 0.0000 & 3.584521 & 1.205471 & 0.0037 & 0.39 \\
\hline 4 & D(VA H52) & D(VA ALL) & 0.020775 & 0.002279 & 0.0000 & 13.46404 & 4.174893 & 0.0017 & 0.48 \\
\hline 5 & D(VA H53) & D(VA ALL) & 0.003878 & 0.000395 & 0.0000 & -1.359416 & 0.711192 & 0.0587 & 0.52 \\
\hline 6 & D(VA H) & D(VA ALL) & 0.080099 & 0.003691 & 0.0000 & 23.66802 & 7.118542 & 0.0012 & 0.83 \\
\hline 7 & D(VA H52) & D(VA H53) & 1.684451 & 0.440622 & 0.0002 & 27.41615 & 5.048911 & 0.0000 & 0.18 \\
\hline 8 & D(VA H52) & D(VA H49) & 0.312116 & 0.048862 & 0.0000 & 13.24658 & 4.907461 & 0.0081 & 0.33 \\
\hline 9 & D(VA H49) & D(VA H53) & 4.684646 & 0.551177 & 0.0000 & 46.69170 & 6.179516 & 0.0000 & 0.50 \\
\hline
\end{tabular}

Data source: [24]; Calculation: Eviews 9.0. 
Vilke S, at al. Correlation Between Freight Transport Industry and Economic Growth - Panel Analysis of CEE Countries

Table 5 - Results of the Panel Generalised Method of Moments First Differences test

\begin{tabular}{||l|c|c|c|c||}
\hline \multicolumn{5}{|c||}{ Dependent variable: VA H49 TOTAL } \\
\hline \multicolumn{1}{||c|}{ Instrument specification: @ DYN(VA H52 TOTAL,-2) } \\
\hline Variable & Coefficient & Std. Error & t-Statistic & Prob. \\
\hline \hline VA H49 TOTAL(-1) & 0.128629 & 0.000362 & 355.1726 & 0.0000 \\
\hline VA ALL TOTAL & 0.055249 & 0.000220 & 250.6738 & 0.0000 \\
\hline Mean dependent var & 103.0215 & S.D. dependent var & & 221.2883 \\
\hline S.E. of regression & 117.5167 & Sum squared resid & & 1408639. \\
\hline J-statistic & 11.64889 & Instrument rank & & 13 \\
\hline Prob(J-statistic) & 0.390605 & & & \\
\hline
\end{tabular}

Data source: [24]; Calculation: Eviews 9.0.

set is appropriate. In continuation we used the Arellano-Bond test to test the residuals for their serial correlation with the variables (Table 6).

The Arellano-Bond serial correlation test statistics shows that the $\mathrm{AR}(1)$ and $\mathrm{AR}(2)$ statistics cannot be rejected at $\mathrm{p}<0.05$ level, pointing to the residuals being serially correlated in levels [17]. Thus we may conclude that the results of the Panel Generalised Method of Moments First Differences test in Table 5 may be rejected due to autocorrelation of residuals. This is one of the rare occasions where the results have been rejected by the post-hoc test. In Table 7, we provide the summary results of all Panel GMM FD test statistics.
As noted before, the results of the regression in row 1 of Table 7 must be rejected due to serial autocorrelation in residuals. The results in row 2 of Table 7 must be rejected due to wrong coefficient signs. The results in row 6 of Table 7 must also be rejected due to wrong coefficient sign of the autoregressive variable. All other results are fully acceptable and commensurate to the results of the Panel EGLS Cross-section fixed effects tests shown in Table 4. Concerning other residuals' post-hoc tests, we did not find any evidence of serial autocorrelation other than the above mentioned, and for that matter no evidence of spatial autocorrelation. A Mantel test would be one way of testing for spatial

Table 6-Results of the Arellano-Bond Residuals'Serial Correlation test

\begin{tabular}{|c|c|c|c|c||}
\hline Test order & m-Statistic & rho & SE(rho) & Prob. \\
\hline \hline AR(1) & -1.375355 & -233068.762758 & 169460.780889 & 0.1690 \\
\hline AR(2) & -1.780589 & -370867.993035 & 208283.892528 & 0.0750 \\
\hline
\end{tabular}

Data source: [24]; Calculation: Eviews 9.0.

Table 7 - Panel Generalised Method of Moments First Differences test statistics

\begin{tabular}{||c|c|c|c|c|c|c|c|c|c||}
\hline Nr. & Dependent & Coeff. $(-1)$ & Std. Error & Prob. & Independent & Coeff. & Std. Err. & Prob. & J-Stat \\
\hline \hline 1 & VA Land trans. & 0.128629 & 0.000362 & 0.000 & VA ALL TOTAL & 0.055249 & 0.000220 & 0.000 & 11.649 \\
\hline 2 & VA Water trans. & 0.519082 & 0.001051 & 0.000 & VA ALL TOTAL & -0.006628 & 0.000120 & 0.000 & 12.601 \\
\hline 3 & VA Air trans. & 0.762680 & 0.006223 & 0.000 & VA ALL TOTAL & 0.032256 & 0.000403 & 0.000 & 10.233 \\
\hline 4 & VA Warehous. & 0.162342 & 0.002971 & 0.000 & VA ALL TOTAL & 0.247346 & 0.000222 & 0.000 & 11.663 \\
\hline 5 & VA Postal & 0.219060 & 0.000629 & 0.000 & VA ALL TOTAL & 0.002300 & $9.86 \cdot 10^{-6}$ & 0.000 & 12.082 \\
\hline 6 & VA H TOTAL & -0.029439 & 0.002107 & 0.000 & VA ALL TOTAL & 0.091881 & 0.000155 & 0.000 & 12.593 \\
\hline 7 & VA Warehous. & 0.786208 & 0.006084 & 0.000 & VA Postal & 1.633438 & 0.016079 & 0.000 & 11.650 \\
\hline 8 & VA Warehous. & 0.288900 & 0.003979 & 0.000 & VA Land trans. & 0.311935 & 0.000469 & 0.000 & 11.362 \\
\hline 9 & VA Land trans. & 0.765974 & 0.006948 & 0.000 & VA Postal & 6.002581 & 0.102766 & 0.000 & 10.852 \\
\hline
\end{tabular}

Data source: [24]; Calculation: Eviews 9.0.

Note: All results have a Prob(J-Statistics) significantly different from zero. 
autocorrelation, but it would necessitate matrices containing measures of distance as idiosyncratic factors which does not make much sense since we are dealing with entire countries and not points (cities). If for that matter any serial correlation would be present, it would show in the Arellano-Bond test for serial correlation. As it may be seen from the performed tests, we first differenced all data and lost the idiosyncratic variables in our EGLS model, as well as in our Panel GMM First Differences model, making our analysis more robust.

\section{CONCLUSION}

There is ample evidence in current literature about correlation between freight transport activities and economic development and evidence that freight transport activities contribute to a country's economic growth, and vice versa, that decrease in economic growth impact on degradation of overall freight transport performance. In this paper it has been concluded that the overall economy (value added and employment) has a statistically significant and measurably strong impact on logistics activity (transportation and warehousing), which is consistent with the most of the results found in literature. Although, there is no systematic research of the relationship between transport industry and economic growth at this level and encompassing this group of countries, thus, there is no relevant comparable research. We tested the counterfactual conditional hypothesis that without economic growth there is no growth in transport industry as measured in the analysed CEE countries. The results do not reject such a conjecture. The main results note the existence of causal relationship between freight transport and economic growth for the analysed panel. This means that any changes in the value added of the overall economy impacts the changes in the warehousing and support activities of the overall transportation and storage sector. In this way, this relationship could be used as a signal for early detection of extreme development problems in freight transportation sector and a good basis for warning the logistics industry about the problem. That is, we could say with high level of reliability that the expected economy decrease of the CEE countries due to the COVID-19 pandemic, would cause a degradation of freight transport activity in this region, most probably in relation to the value of the GDP decrease in these countries.
Regarding future work, it would be interesting to extend the analysis by including more parameters of economic development, in order to explore the exact magnitude of economic crises on freight transport intensity in a given region. Another direction that future research could follow is extending the analysis to other contexts taking into account evolutionary changes in the structure of the economy (on national and international level).

Dr. sc. SINIŠA VILKE, izv. prof. ${ }^{1}$

E-mail: svilke@pfri.hr

Dr. sc. DAVOR MANCE, doc. ${ }^{2}$

E-mail: davor.mance@efri.hr

Dr. sc. BORNA DEBELIĆ, izv. prof. ${ }^{1}$

E-mail: debelic@pfri.hr

Dr. sc. MARINKO MASLARIĆ, izv. prof.3

E-mail: marinko@uns.ac.rs

${ }^{1}$ Sveučilište u Rijeci, Pomorski fakultet

Studentska ulica 2, 51000 Rijeka, Hrvatska

${ }^{2}$ Sveučilište u Rijeci, Ekonomski fakultet

Ul. Ivana Filipovića 4, 51000 Rijeka, Hrvatska

${ }^{3}$ Univerzitet u Novom Sadu, Fakultet tehničkih nauka

Trg Dositeja Obradovića 6, 21000 Novi Sad, Srbija

\section{KORELACIJA IZMEDU INDUSTRIJE TERETNOG PRIJEVOZA I GOSPODARSKOG RASTA: PANEL ANALIZA CEE ZEMALJA}

\section{SAŽETAK}

U radu se ispituje statistička povezanost između zaposlenosti i dodane vrijednosti industrije teretnog prijevoza i njegovih komponenti u odnosu na cjelokupno gospodarstvo na desetogodišnjem panelu u razdoblju od 2008. do 2017. godine za trinaest najnovijih zemalja članica Europske unije. U ovom se radu ispituje korelacija između gospodarskog rasta kao nezavisne varijable $i$ teretnog prijevoza kao zavisne varijable. Da bi se postigla stacionarnost te izgubili autokorelacija i idiosinkratski učinci, varijable se prvo diferenciraju. Rezultati testova „, Granger kauzalnosti “ pokazuju da se nul hipoteza neuzročnosti može odbaciti s visokom F-statistikom i niskim p-vrijednostima. Rezultati panel analize temeljem metode fiksnih učinaka su sukladni rezultatima testa panel Granger kauzalnosti, a isto se može reći i za test generalizirane metode momenta. Rezultat Arellano-Bond testa ne ukazuje na postojanje serijske korelacije reziduala. Zaključeno je da promjene u ukupnom gospodarstvu (dodana vrijednost i zaposlenost) imaju statistički značajan i mjerljivo snažan utjecaj na sektor teretnog prijevoza i skladištenja. Ovaj je zaključak koristan u procjeni budućih utjecaja na industriju teretnog prijevoza, s naglaskom na posljedice nepredvidivih događaja.

\section{KLJUČNE RIJEČI}

industrija teretnog prijevoza; logistika; gospodarski rast; panel analiza; povezanost. 
Vilke S, at al. Correlation Between Freight Transport Industry and Economic Growth - Panel Analysis of CEE Countries

\section{REFERENCES}

[1] ADB. Transport efficiency through logistics development: Policy study. Mandaluyong City, Philippines: Asian Development Bank; 2012.

[2] Prusa P, Jovcic S, Samson J, Kozubikova Z, Kozubik A. Using a non-parametric technique to evaluate the efficiency of a logistics company. Transport Problems. 2020;15(1): 153-161. DOI: 10.21307/tp-2020-014

[3] Burdzik R, Ciesla M, Sladkowski A. Cargo loading and unloading efficiency analysis in multimodal transport. Promet - Traffic\&Transportation. 2014;26(4): 323-331. DOI: $10.7307 /$ ptt.v26i4.1356

[4] Saidi S, Hammami S. Modeling the causal linkages between transport, economic growth and environmental degradation for 75 countries. Transportation Research Part D. 2017;53: 415-427. DOI: $10.1016 /$ j.trd.2017.04.031

[5] Gao Y, Chang D, Fang T, Luo T. The correlation between logistics industry and other industries: An evaluation of the empirical evidence from China. The Asian Journal of Shipping and Logistics. 2018;34(1): 027-032. DOI: 10.1016/j.ajsl.2018.03.004

[6] Mankowski C, Weiland D, Abramovic B. Impact of railway investment on regional development-case study of Pomeranian metropolitan railway. Promet Traffic\&Transportation. 2019;31(6): 669-679. DOI: 10.7307/ptt.v31i6.3231

[7] OECD/ITF. Globalisation, crisis and transport. Discussion paper No.:2009-12 of the International Transport Forum, Leipzig, 2009.

[8] Moschovou TP. Freight transport impacts from the economic crisis in Greece. Transport Policy. 2017;57: 5158. DOI: 10.1016/j.tranpol.2017.04.001

[9] Kaplan LC, Kohl T, Martinez-Zarzoso I. The effects of the CEECS's accession on sectoral trade: A value added perspective. University of Gottingen, Center for European, Governance and Economic Development Research. Discussion Papers: 272, 2016.

[10] Dedik M, Gasparik J, Zahumenska Z, Luptak V, Hrebicek Z. Proposal of the measures to increase the competitiveness of rail freight transport in the EU. Nase more. 2018;65(4): 202-207. DOI: 10.17818/NM/2018/4SI.7

[11] Husakova N. Tools for effective application of eco-logistics. In: Proceedings of the Carpathian Logistics Congress - CLC' 2013, 9-11 December 2013, Cracow, Poland. Ostrava, Czech Republic: TANGER Ltd; 2014. p. 80-84.

[12] Fedorko G, Molnar V, Honus S, Neradilova H, Kampf R. The application of simulation model of a milk run to identify the occurrence of failures. International Journal of Simulation Modelling. 2018;17(3): 444-457. DOI: 10.2507/IJSIMM17(3)440

[13] Mohammad R. The relationship between logistics and economic development in Indonesia: Analysis of time series data. Journal Teknik Industri. 2013;15(2): 119-124.
DOI: 10.9744/jti.15.2.119-124

[14] Zhu F, Wu X, Gao Y. Decomposition analysis of decoupling freight transport from economic growth in China. Transportation Research Part D. 2020;78: 102201. DOI: 10.1016/j.trd.2019.12.003

[15] Fang B, Han X. Relating transportation to GDP: Concepts, measures and data. MacroSys Research and Technology. Discussion Papers, 2000.

[16] Gao Y, Zhang Y, Li H, Peng T, Hao S. Study on the relationship between comprehensive transportation freight index and GDP in China. Procedia Engineering. 2016;137: 571-580. DOI: 10.1016/j.proeng.2016.01.294

[17] Alises A, Vassallo JM. The impact of the structure of the economy on the evolution of road freight transport: A macro analysis from an input-output approach. Transportation Research Procedia. 2016;14: 2870-2879. DOI: 10.1016/j.trpro.2016.05.404

[18] Brunel J. Freight transport and economic growth: An empirical explanation of the coupling in the EU using panel data. Discussion Papers HAL Id: halshs-00004826, 2005.

[19] Gani A. The logistics performance effect in international trade. The Asian Journal of Shipping and Logistics. 2017;33(4): 279-288. DOI: 10.1016/j.ajs1.2017.12.012

[20] Muller S, Klauenberg J, Wolfermann A. How to translate economic activity into freight transportation? Transportation Research Procedia. 2015;8: 155-167. DOI: 10.1016/j.trpro.2015.06.051

[21] Rabinovich E, Cheon S. Expanding horizons and deepening understanding via the use of secondary data sources. Journal of Business Logistics. 2011;32(4): 303-316. DOI: $10.1111 / \mathrm{j} .0000-0000.2011 .01026 . x$

[22] Ellram LM, Tate WL. The use of secondary data in purchasing and supply (P/SM) management research. Journal of Purchasing \& Supply Management. 2016;22(4): 250-254. DOI: 10.1016/j.pursup.2016.08.005

[23] Busse C. A procedure for secondary data analysis: Innovation by logistics service providers. Journal of Supply Chain Management. 2010;46(4): 44-58. DOI: 10.1111/j.1745-493X.2010.03205.x

[24] European Commission. Directorate General for Internal Market, Industry, Entrepreneurship and SMEs. SME Performance Review. Brussels; 2019.

[25] NACE. Regulation (EC) No 1893/2006 of the European Parliament and of the Council of 20 December 2006 establishing the statistical classification of economic activities NACE Revision 2 and amending Council Regulation (EEC) No 3037/90 as well as certain EC Regulations on specific statistical domains. Official Journal of the European Union. 2006;393: 1-39. DOI: http://data.europa.eu/ eli/reg/2006/1893/oj

[26] Arellano M, Bond S. Some tests of specification for panel data: Monte Carlo evidence and an application to employment equations. The Review of Economic Studies. 1991;58(2): 277-297. DOI: 10.2307/2297968 